\title{
THE REASONS TO LACK OF ELECTRONIC BANKING ACHIEVEMENT IN IRAN
}

\author{
Dr. Mohsen Rasoulian and Monire Safari \\ Islamic Azad University, Naragh Branch ,Iran \\ m_rsl@yahoo.com \\ Monire.safari@yahoo.com
}

\begin{abstract}
:
Back ground: electronic banking is an important and fundamental issue that plays an important role in reaching to electronic government. Generally speaking electronic banking includes all banking services using electronic system by the virtue of safe mediators in a way that physical presence is no longer necessary. The beginning of electronic banking turns back to 1960s when computers were used in banks for the first time. The second round of electronic banking started at late 1970s and it was named automation of the office. Using telecommunication services was also common in this period. The third round started in the middle of 1980s by connection of customers to accounts. In this round the connection of customers with their accounts, telephone, ATM, etc was used. Finally, fourth period was accompanied by uniting the systems and connecting the customer to all banking operations. The beginning of electronic banking in Iran goes back to 1981-1991. Tejarat bank issued the first bank card in 1991 and after that Sepah bank started to establish 7 ATM stands all over the country. In 1992 Iran joined SWIFT(Society for Worldwide Interbank Financial Telecommunication ) international channel and it was connected to the channel in 1993.

Methods: The type of study is operational from the perspective of its aim and practical from the perspective of its implementation and it includes two parts. The first part is concerned with a comparison of banking systems in Turkey-Malaysia and Iran. The second part is however concerned with the obstacles in the way of electronic banking in Iran including: management obstacles, financial obstacles, technical obstacles, cultural obstacles and safety obstacles. It is attempted to use statistics from the organizations like central bank, telecommunication center, etc and study the amount of influence in each of them. Statistical data used in this study is during 20102011.

Results: The result of the first chapter of the present study is the importance of Internet, frameworks and encouraging policies to impress beneficiaries to use electronic banking. The second part introduces the cultural elements as the most important ones and then it attracts our attention to financial elements (the cost of Internet and commissions) as the second influencing factor the influence of technical elements is fading away due to the improvements in banking system. Different parameters like management obstacles also play an important role in the way of electronic banking. The safety obstacles are influenced by the cultural issues and their direct influence is not certified. Ghareche and Abdolbaghi introduce Internet foundation and decrease in service expenses, managers and experts, that this study confirms Internet foundation and decrease in service expenses. Moghali confirm culture as effective parameter (indirectly). Amade and Jafarpour introduce culture-social, management and reject financial and technical parameters, that this study only confirms culture-social parameters as effective parameter.

Conclusion: The result of study does not certify the safety obstacles and cultural, financial, and technical management obstacles are influencing respectively.
\end{abstract}

\section{KEYWORDS:}

Electronic banking, management obstacles, financial obstacles, technical obstacles, cultural obstacles 
International Journal of Managing Information Technology (IJMIT) Vol.3, No.3, August 2011

\section{INTRODUCTION:}

Electronic banking has many advantages and interesting diversities including more number of customers, services in higher quality and lower price, preservation and enhancement of share in market, unlimited space for market, concentration in new distribution, making competition between commercial brands, concentration on expenses and improvement of revenue, providing extensive services, improvement in management system, decreasing the expenses of contractions, close intra banking connection, controlling ecological pollution, etc.

The implementation of article 44 of constitutional law and manifestation of electronic government can make electronic banking much more serious. Also electronic trade requires electronic banking. Besides, in recent years sanctions have influenced all current issues and electronic banking can be affective in breaking suctions. (But also suctions can be effective communication with foreign banks...). Also in recognizing financial operation of competitors it can be very useful. Existence of a comprehensive electronic banking system can prevent the process of launder in the country and can minimize tax violation, fabrication of banking documents and monetary theft. Electronic banking has different models like internet banking, telephone banking, cell phone banking and related technologies like ATM, POS, electronic links, etc.

\section{OVER VIEW OF STUDIES:}

Alireza Moghali (1386) considers the importance of electronic banking and discusses its advantages in an article titled "the acceptance of electronic banking in customers in Shiraz." The education of customers is of real importance in this regard as well. Atousa Goudaezi and Vahid Zobeidi (1387) discussed the influence of electronic banking in profits made by the banking system. Hamide Amade and Mahmoud Jafarpour (1388) studied the 4 groups of obstacles in a research titled "the study of obstacles and strategies to improve electronic banking in perspective of Iran 1404." These obstacles include cultural-social, management, financial and technical ones and the first two are accepted and the second two are rejected at the end of the study. In another article written by Mohammadreza Hamidizadeh and Manije Ghareche and Abdolhamid Abdolbaghi (1386) some other factors such as decrease in service expenses, managers and experts are taken into account as influencing on electronic banking system. They also introduce factors like lack of Internet foundation and lack of experts as the important challenges in the field of electronic banking.

\section{METHODS:}

\subsection{First part- Comparative study:}

In this part it is tried to compare the actions taken in Turkey and Malaysia with Iran. Malaysia is the model of our Islamic country in the field of banking so taking it into consideration can be very helpful. Turkey is a country with a similar religion and culture and is located near our country so that we can study this country in respect of similar affordability of the people in Turkey and Iran.

\subsection{The comparison of electronic banking in Iran and Turkey}

The banking industry of Turkey started in 1990. In 1992 CBT was established to organize the transformations related to this issue. In 2000 a new round was started in Turkey in the field of 
International Journal of Managing Information Technology (IJMIT) Vol.3, No.3, August 2011

electronic banking by introducing new operations and alterations in signatures in software and hardware systems (electronic signature). EST (Electronic Securities Transfer) is used for purchasing and other system were implemented for other purposes like EFT. These items were protected by the government.

In Iran, the commencement of electronic banking turns back to 1381-1391. From 2001 the comprehensive paying system is defined and its operational levels are under construction. By the end of implementation levels all banking operations will be done by the use of electronic system. The comprehensive paying system includes: 1 - Shetab system that has been implemented in 2001 . 2- SATNA system that has been established in 2006. 3- Paya system. 4 -TABA systems. 5- the providers of paying services. 6- Sheba System 7- NAMAD systems

In this part Iran and Turkey are compared form different perspectives:

Internet: based on a plan designed by the Turkey government, most residents of big cities in this country are connected to Internet with the speed of $32 \mathrm{MB}$ per second. Based on a report issued by a site named InternetWorldStats, Iran stands in 34/9 place in regard of Internet use in the middle east. Zionist regime has allocated the $74^{\text {th }}$ stand and has won the first place. After that, Emirates stands in $48 / 9^{\text {th }}$ place, Qatar stands in $42 / 6^{\text {th }}$ place and Lebanon stands in $39 / 5^{\text {th }}$ place respectively. The amount of influence in Turkey is 35 and it stands in $26 / 5^{\text {th }}$ place that is higher than the position of Iran.

The fundamental investments: This country is making the largest optical cable in the region and a consortium of 7 operators from 5 countries is involved in the project. The fiber optics is able to transfer 12.8 terabytes of data per second. Based on this plan VDSL2 will be delivered to the customers and it increases the speed of Internet in Turkey 8 as much. The expense of $16 \mathrm{MB}$ service is 105 Dollars per month and the expense of $32 \mathrm{MB}$ service is 138 Dollars per month. VDSL2 Internet lines are established in 73 cities of Turkey and this plan will be finished within a few months.

In Iran the similar plans are not predicted by any related organizations yet.

The Internet expense: The organization for Radio connections has designed the below table to show the expenses of Internet with a $20 \%$ discount (1389).

\begin{tabular}{|c|c|}
\hline The width of band (Byte per second) & The rlated rade (Toman) \\
\hline $64 \mathrm{~KB}$ & 86800 Tomans \\
\hline $128 \mathrm{~KB}$ & 173600 Tomans \\
\hline $256 \mathrm{~KB}$ & 260400 Tomans \\
\hline $512 \mathrm{~KB}$ & 434000 Tomans \\
\hline $1024 \mathrm{~KB}$ & 781200 Tomans \\
\hline
\end{tabular}


International Journal of Managing Information Technology (IJMIT) Vol.3, No.3, August 2011

\begin{tabular}{|c|c|}
\hline $2048 \mathrm{~KB}$ & 1388800 Tomans \\
\hline $4 \mathrm{MB}$ & 2343600 Tomans \\
\hline $8 \mathrm{MB}$ & 2906000 Tomans \\
\hline
\end{tabular}

These prices are 12 times higher than the prices in Turkey. (The Tomans is a super unit of the official currency of Iran, the rial)

Credit cards: Based on a report issued by The Nilson Report Magazine more than $50 \%$ of Debit card exporters are categorized as Credit card exporters and only 25\% of Credit exporters are categorized under the group of Debit exporters. So that it can be concluded superior card exporters are more into exporting credit cards and about $90 \%$ of the transactions are because of credit transactions. Also it is important to know that the average amount of exporters' transactions in Asia is 22.9 milliard dollars for credit cards and 3 milliard dollars for debit cards. This issue shows the attraction of credit cards for its exporters so for this comparison only credit cards are used. The total amount of credit card issuance in Iran was $0.0006 \%$ until 2010, May and it was $63 \%$ in Turkey which means 45 million and 65 thousand credit cards were issued in Turkey when there were only 442139 thousand cards in Iran.

\subsection{The comparison of electronic banking in Iran and Malaysia}

In 1975 the electronic banking activities started in Malaysia. In the first round that last until 1970, the complementary operations were done to open the financial sectors. Then in 1980, ATM was established as the first manifestation of electronic banking. In 1997 CDMs (Cash Deposit Machines) were provided that completed ATM systems. In later rounds in 1990 Tele -banking started its activity that enjoyed AVR technology and was provided with equipments such as checking the account, intra bank transactions, trust fund, credibility, bill payment card and monetary transactions. After that PC-Banking started its activity in 1995 and it was welcomed by giant companies. Finally, internet banking was established in 1998 and was completed in 2002 (electronic wallet that was cheaper that credit card). The banks in Malaysia had the chance to use different channels to use services including: PC-Banking, Tele -banking, BSN, ATM, EBC (Electronic Banking Center) and virtual stands.

The virtual branches including EBC and stands can be seen in shopping centers and administrations. Virtual stands include: PALPHONE, PALPOINT, PALWORLD and PALTELLER that use a touch screen for its operations and it can talk to the customer and see him at the same time. In 1996 SFNB systems were established for the security of banking system. The supports of Malaysia: In 1994 the Malaysian government started to encourage customers to pay fewer taxes in this regard. Privatization of banks in this country was a big step in the way of electronic banking. Association of Banks in Malaysia (ABM) was established in 1973 to make an order in AMB systems by having a connection with credit card exporters (installation of security chips on credit cards) and also being pioneer in modernization of its banks and introducing new banking strategies to the people of Malaysia.

The instruments of electronic banking in Malaysia have much more considerable diversity as they do in Iran. In Iran many machines are capable of only a few tasks like telephone bank and ATM. Some electronic banking instruments that are used in Malaysia are not even introduced in Iran 
International Journal of Managing Information Technology (IJMIT) Vol.3, No.3, August 2011

like electronic wallet, stands, and conference video that increase the safety of users but such things are not possible in Iran.

Internet: The speed of Internet in this Islamic country is 160 times more than Iran and its expense is 3000 Tomans per Megabyte and in many places people are provided with wireless system for free. Wimax Internet service is delivered to people for 23000 Tomans per Megabyte in this country. The users pay only 1/58 dollars per month for 224 MB Internet (about 1500 Tomans). It can be concluded that the expense of Internet in this country is 16 times more than Iran.

\section{Section 2- The reasons to lack of electronic banking system in Iran:}

First assumption: the cultural elements are the most important ones in this regard.

Second assumption: the financial elements are the most important ones in this regard.

Third assumption: the technical elements are the most important ones in this regard.

Fourth assumption: the management elements are the most important ones in this regard.

Fifth assumption: the safety elements are the most important ones in this regard.

Standard measures are used to discuss the influence of all above mentioned elements.

\section{A) Cultural obstacles:}

Before we go to cultural obstacles it should be mentioned that culture is acquired so the elements that are discussed hereunder are due to lack of education and information.

These elements include: lack of information among electronic bank users, the resistance of beneficiaries toward electronic banking, lack of the culture to use electronic bank system and IT. In order to study the influence of this element, we can use the statistics provided by central bank and the statistics center of Iran.

Based on the declaration of Iran's statistics organization, the population of each province is listed in following:

5 populated provinces of Iran are: Tehran ,Razavi Khorasan, Isfahan, Fars and Khouzestan and on the other hand Ilam, Semnan, Kohkiluye and Boyer Ahmad, Southern Khorasan and Northern Khorasan are less in population.

The central bank did not provide statistics regarding the amount of transactions of other banking models like internet transactions and it only provided information about the transactions in ATMs and POS. It seems like other types are not very popular in the country yet. As a result we just discuss ATM and POS in this study (until2011/2/19): The result of the study is summarized in below table: 
International Journal of Managing Information Technology (IJMIT) Vol.3, No.3, August 2011

\begin{tabular}{|c|c|c|}
\hline Ratio & The highest ratio & The lowest ratio \\
\hline $\begin{array}{l}\text { Population } \\
\text { to ATM }\end{array}$ & $\begin{array}{l}\text { Semnan(2347.678), Tehran(2679.60) } \\
\text { Ilam(3094.71),Boushehr(3406.26), } \\
\text { Zanjan(3811.61), Isfahan(396081) }\end{array}$ & $\begin{array}{l}\text { Sistanbalouchestan(8594.98), } \\
\text { W.Azarbayjan(6336.77),Khuzastan(5696.16), } \\
\text { Lorestan(5960.09),Golestan(5549.62), } \\
\text { E.Azarbayjan(5525.85) }\end{array}$ \\
\hline $\begin{array}{l}\text { Population } \\
\text { to POS }\end{array}$ & $\begin{array}{l}\text { Ardebil(0.005619),Isfahan(06773), } \\
\text { Boushehr(2.7169), } \\
\text { S.Khorasan(7.1333), } \\
\text { N.Khorasan(21.5448), } \\
\text { Yazd(33.1878) }\end{array}$ & $\begin{array}{l}\text { R.Khorasan(597.1819),Kermanshah(334.64), } \\
\text { Fars(264.6861),Khuzestan(234.9458), } \\
\text { W.Azarbayjan(157.3941), } \\
\text { E.Azarbayjan(151.8979) }\end{array}$ \\
\hline $\begin{array}{l}\text { Population } \\
\text { to issued } \\
\text { cards }\end{array}$ & $\begin{array}{l}\text { Tehran(0.4368), semnan }(0.5893) \text {, } \\
\text { Yazd(0.649),Markazi }(0.7712) \\
\text {,Qom(0.7924), Isfahan(0.8146) }\end{array}$ & $\begin{array}{l}\text { Sistanbaluchestan(1.7749), } \\
\text { W.Azarbayjan(1.4536),Hamedan(1.2631), } \\
\text { N.Khorasan(1.1908),Lorestan(1.1858), } \\
\text { Kordestan(1.1615) }\end{array}$ \\
\hline $\begin{array}{l}\text { Population } \\
\text { to ATM } \\
\text { transaction }\end{array}$ & $\begin{array}{l}\text { Tehran }(0.4119), \text { Yazd }(0.4748) \\
\text { Ilam }(0.5096), \text { Boushehr }(0.5100) \\
\text { Semnan }(0.5380), \text { Isfahan }(0.5739)\end{array}$ & $\begin{array}{l}\text { W.Azarbayjan(1.1262) } \\
\text {,Sistanbaluchestan(1.0884),Hamedan(0.9790), } \\
\text { Golestan(0.8529),N.Khorasan(0.8368), } \\
\text { Ardebil(0.8231) }\end{array}$ \\
\hline $\begin{array}{l}\text { Population } \\
\text { to POS } \\
\text { transactions }\end{array}$ & $\begin{array}{l}\text { Boushehr(0.1190), } \\
\text { S.Khorasan(0.2848),Ardebil(0.7), } \\
\text { N.Khorasan(0.8061), Kohkiluye and } \\
\text { BoyerAhmad(1.4257),Zanjan(1.4830) }\end{array}$ & $\begin{array}{l}\text { Tehran(93.608),Isfahan(53.2491), } \\
\text { R.Khorasan(25.9525),Fars(15.4452), } \\
\text { Khuzestan(15.0435), Kermanshah(13.6592) }\end{array}$ \\
\hline
\end{tabular}

\section{B) Financial obstacles:}

Every alteration requires foundation, support and expertise. The possibility to have suitable foundations, updated equipments and support groups requires a considerable amount of money. In fundamental changes of the society such as electronic banking this issue is of even more importance. Lack of investment in the field of telecommunication, expenses regarding web connection, satellite expenses, the expenses for up grading webs are some examples in this regard.

The average speed of Internet is $128 \mathrm{~Kb}$ per second and it costs 20000 Tomans monthly. About using ATM and POS machines it should be said that the banks keep receiving commissions. Telecommunication center is not faced with serious financial problems in this regard.

\section{C) Technical obstacles:}

Electronic banking is dependant to updated and useful technology. Lots of are required in this regard at the same time like telecommunication, information technology, etc.

The influencing factors on electronic banking are: access to web, internet speed, ISP centers, number and width of internet bands, lack of IT and electronic banking experts, lack of quality, ICI expansion, disqualified electronic banking services, etc.

In order to discuss this issue we need the statistics issued by telecommunication center and central bank. The below chart is used in the site of telecommunication center to show the operations of the said organ: 
International Journal of Managing Information Technology (IJMIT) Vol.3, No.3, August 2011

\begin{tabular}{|c|c|l|l|l|l|l|l|}
\hline Row & Index & 1384 & 1385 & 1386 & 1387 & 1388 & 1389 (May) \\
\hline 1 & $\begin{array}{c}\text { telephone } \\
\text { division }\end{array}$ & 20340060 & 22626944 & 23952089 & 24709447 & 25410361 & 24972645 \\
\hline 2 & $\begin{array}{c}\text { Telephone } \\
\text { influence }\end{array}$ & 2971 & 3257 & 3345 & 3395 & 3404 & 3360 \\
\hline 3 & $\begin{array}{c}\text { Cell phone } \\
\text { division }\end{array}$ & 8510513 & 15385289 & 24509714 & 31423104 & 35427101 & 35554812 \\
\hline 4 & $\begin{array}{c}\text { Cell phone } \\
\text { influence }\end{array}$ & 1243 & 2220 & 3420 & 4320 & 4790 & 4792 \\
\hline 5 & $\begin{array}{c}\text { Connected } \\
\text { villages }\end{array}$ & 47955 & 51058 & 52784 & 52459 & 52596 & 52600 \\
\hline 6 & $\begin{array}{c}\text { ICT } \\
\text { villages }\end{array}$ & 963 & 2287 & 5590 & 8200 & 9812 & 9900 \\
\hline 7 & $\begin{array}{c}\text { Public } \\
\text { phone }\end{array}$ & 141912 & 167366 & 186198 & 218719 & 22800 & 229000 \\
\hline 8 & $\begin{array}{c}\text { Public toll } \\
\text { call }\end{array}$ & 64774 & 89460 & 124314 & 162055 & 176800 & 177000 \\
\hline 9 & Data ports & 14897 & 16392 & 36806 & 50818 & 91016 & 98547 \\
\hline 10 & $\begin{array}{c}\text { Internet } \\
\text { users }\end{array}$ & 880000 & 12000000 & 12800000 & 21000000 & 26500000 & 26800000 \\
\hline & $\begin{array}{c}\text { Info } \\
\text { transfer } \\
\text { web }\end{array}$ & 716 & 956 & 1182 & 1220 & 1223 & 1223 \\
\hline 11 & & & & & & \\
\hline
\end{tabular}

Fiber optics are about $47000 \mathrm{Km}$ in Iran.

By comparing the internet users to the population of the country it can be concluded that the number of internet users is very few in Iran.

Based on the ranking of countries in respect of personal internet speed in first half of 2010, 152 countries were studied and Iran has the $144^{\text {th }}$ place after Venezuela, Nigeria, Bolivia, Iraq, Prague, Turkey and kayaks with the speed of $0.61 \mathrm{MB}$ per second.

The width of imported international internet band: $1705 \mathrm{Mbps}$, The width of exported international internet band: $1705 \mathrm{Mbps}$, number ISP: $\mathrm{t}$ 1370, the capacity of information transfer: 106000 MB, Fiber optics: 56000 Km.

About the speed of problem solving no statistics have been issued.

About the number of IT-EB experts it should be mentioned that from 1381 the university acceptance in the field of IT MA and BA is started and in the field of EB there's no official training course and the problem of IT graduates is lack of experience due to its new nature.

The telecommunication center is expected to provide the needs of banks but no statistics have been delivered in this regard. But based on the issued statistics by central bank about the transactions it can be understood that the banks are improving their electronic bank services all over the country and it's a sign of telecommunication services to the banks. 


\section{D) Management obstacles:}

There are many reasons to lack of electronic banking from the perspective of management role and the most important ones are: tendency to previous processes, low risk ability, changes made in board of managers, the existence of many decision making organs, long term management, the amount of knowledge, lack of familiarity with electronic banking and vague policies.

In recent years central bank and some other banks witnessed the changes made in board of high ranking managers. First of all we are going to discuss the actions taken by Sheibani, Mazaheri, Bahmani and Nourbakhsh in regard of electronic banking.

Nourbaksh was the chairman of central bank in 1994-2003 and he took the first steps in the field of electronic banking. After him Sheibani started his career as the chairman of central bank from 2003-2007 and his important actions were listed in the report of 2006 as: the daily liquidation of Shetab centers, SATNA establishment, and the expansion of credit and debit cards. After him Mazaheri provided services such as fast monetary transactions, ATM, PINPAD, SATNA and issuance of credit cards during 2007-2008. Then Bahmani started his job from 2008 and his services include: SHEBA, Card to card transaction, Mirror and DR supporting sites, etc. you can see no considerable changes can be observed in management methods of all mentioned managers. Based on by laws of banking system enacted on 2004, the central bank is responsible for determination of strategies and foundations of electronic banking system.

Due to the adherence of all banks all over the country from the central bank it can be concluded that the actions taken by the managers of different banks is toward electronic banking so the existence of many decision making organs does not seem to be true. But the different services provided in different banks with similar banking policies is because of the different actions of middle ranking managers so middle ranking managers can be influential in this regard.

\section{E) Safety obstacles and acceptance of risks:}

Regarding this item we first discuss all possible risks in banking system:

In evaluation of risk in electronic banking system we can use the below items: 1 the recognition of risk by customer. 2 the ability of customer to analyze the capabilities of the system 3 sensitivity to information preservation by bank and customer

Regarding the discussed issues, safety measurements and risking in electronic banking include: lack of legal encounter with violations made in the field of electronic banking, the use of multi functional factors by banks, lack of enough attention to preservation of information by customer and bank, the passive attitudes of banks towards the safety issues, the risks caused by cheating, etc.

In order to determine the amount of influence of the above mentioned factors we used the statistics provided by the Police and central bank:

Based on a report issued by the police, the most electronic crimes occur in banking system. Based on a report issued by the deputy special crimes officer, $33 \%$ of cases are about illegal access to systems and computer data by using bank cards and electronic devices. 
International Journal of Managing Information Technology (IJMIT) Vol.3, No.3, August 2011

Central bank stated that this issue is because of lack of attention of people in preserving their passwords. This problem can be solved by the use of electronic signatures. In 1388 central bank started its activity in regard of electronic signature. So it can be concluded that abuses are because of ignorance of people about safety issues and banking system itself is provided with enough security measurement.

\section{FINDINGS:}

Based on the result of this study cultural factors can be categorized in this way: 1. the dispersal of ATM, POS is not related to the population of each city. 2. This issue can also be seen in card issuance by the banks as well. 3. The number of issued cards is more harmonic with ATM than it is with POS. 4. The provinces with large amounts of ATM, POS have the highest amount of transaction. 5. The provinces with small amounts of ATM, POS have lower amount of transaction. 6. Commissions exist in both items so financial issues are not influential in this regard. Generally, it can be concluded that cultural issues are very influential. ATM was used before POS and that's why people are much more familiar with that. So the influence of issued cards can be seen in ATM transaction and provinces such as Tehran and Isfahan have a suitable proportion of POS but because people are not familiar with that it has a low transaction amount (while it was expected to have the highest transactions). In financial elements we can conclude that financial obstacles affect the use of people from banking services but the custodian organizations are not faced with this problem in the field of electronic banking. Regarding technical obstacles it can be said that because of the importance of internet in this regard this can be an influential factor but its influence is fading away due to the actions under operation. Regarding management obstacles only middle ranking managers can be influential. About safety obstacles it should be said that it is affected by cultural elements because it can be reduced by instruction so safety obstacles are not very serious for electronic banking in Iran.

\section{CONCLUSION:}

From the first section it can be concluded that internet is a very important element in this regard. Reduction in its price, increasing its speed, paying attention to the expansion of credit cards, expansion of banking services and paying attention to foundations especially privatization can encourage people to take advantage o this system. In the second section this issue is stressed as well (confirmation of first assumption). Also Ghareche and Abdolbaghi introduce Internet foundation and decrease in service expenses and Moghali also confirm culture as effective parameter (indirectly). Second assumption: financial elements affect the way people use these services so after cultural elements, they take the second place. Third assumption: because of the current improvements the influence of this factor is fading away. Fourth assumption: only middle ranking managers are considered as influential. Amade and Jafarpour introduce culture-social, management and reject financial and technical parameters, that this study only confirms culturesocial parameters as effective parameter. Fifth assumption: these obstacles do not play an important role in electronic banking system and are influenced by cultural factors. Totally it can be said that cultural, financial, management and technical obstacles are influential respectively.

\section{REFRENCES:}

[1] Authentication in an internet banking environment- federal financial institutions examination council2000- http://www.ffiec.gov (2...). 
International Journal of Managing Information Technology (IJMIT) Vol.3, No.3, August 2011

[2] Effective of electronic banking facilities, employment sector and age group on customers' choice on banking Nigeria- journal of internet banking and commerce- jibca 2010, vo. 152, No. 1. http://www.ayardev.com/commerce/gibc

[3] Connel Fullenkamp \& Saleh M. Nsouli, "six puzzles in electronic money and banking".

[4] Payment systems in Turkey- Bulletin central bank of the republic of Turkey-September 2008.

[5] Committee on payment and settlement system- CPSS- payment system in Turkey- www.bis.org.

[6] E. Anguelov. Marianne A.hilgert Jeanne M. Hogarth2004- U.S consumers and electronic banking 1995-2003

[7] Electronic banking in Malaysia: a note on evolution of services and customer reactions. Balachandher Krishnan Guru, Santa Vaithilingam, Norhazlin Ismail, Rajendra Prasad JIBC.

[8] Suganthi, Balavhandher \& Balachandran- internet banking patronage: an empirical investigation of Malaysia. GHBC-2000.

[9] Classifying Users and Non-Users of Internet Banking in Northern Malaysia ,T. Ramayah, Fauziah Md. TaibKoay Pei Ling : Journal of Internet Banking and Commerce, August 2006, vol. 11, No.2

[10] Imtiyaz Al-Sabbagh \& Alemayehu Molla , Adoption and Use of Internet Banking in the Sultanate of Oman : An Exploratory Study

[11] JOSHUA ABOR ,Technological Innovations and Banking in Ghana: An Evaluation of Customers' Perceptions

[12] Suganthi, Balachandher, Balachandran , Internet Banking Patronage: An Empirical Investigation of Malaysia. Journal of Internet Banking and Commerce ,2001.

[13] Hamid Amade, Mahmoud Jafarpour,(1388), "The strategies to expand electronic banking system, Iran "1404", danesh and tose'e magazine, No. 26.

[14] Alireza Moghali (1386), "The acceptance of electronic banking in customers in Shiraz" ,management science of Iran Journal , No.7

[15] Atousa Goudaezi \& Vahid Zobeidi (1387), "Review effect of expansion of electronic banking on commercial banks", Economic Research of Iran Journal. No35 -1387

[16] Hamide Amade \& Mahmoud Jafarpour (1386), "the study of obstacles and strategies to improve electronic banking in perspective of Iran 1404", Humanities and social sciences, especially management journal .No27

[17] Ali Akbar Goy Ababdi (1386), "Electronic Banking A selection or a requirement take accordance with access and technology", export development Bank magazine 